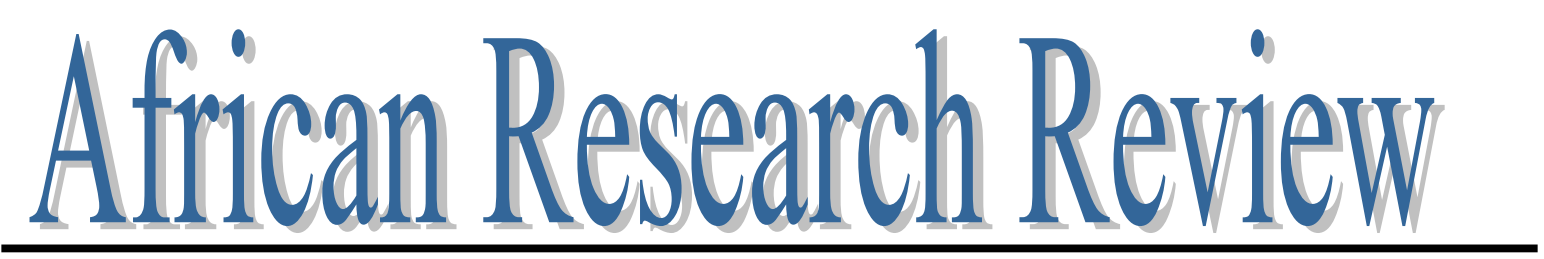

An International Multidisciplinary Journal, Ethiopia

Vol. 8(3), Serial No. 34, July, 2014:123-139

ISSN 1994-9057 (Print) ISSN 2070--0083 (Online)

DOI: http://dx.doi.org/10.4314/afrrev.v8i3.11

\title{
Relationships between Soil and Vegetation Structural Properties of Secondary Forest Regenerating in Degraded Rubber Plantation in the Niger Delta Area of Nigeria
}

\author{
Ichikogu, V. I. \\ C/O Professor A.O. Aweto, Department of Geography \\ Faculty of Social Sciences, University of Ibadan, Ibadan \\ Oyo State Nigeria \\ E-mail: Ichikoguvictor@yahoo.com
}

\begin{abstract}
The effects of soil on vegetation structural attributes (tree density, tree height, tree diameter, basal area and estimated aboveground biomass) of a secondary forest following the abandonment of a degraded rubber plantation in Orogun area of Delta state Nigeria was studied using the multiple linear regression model. Four secondary forests of different age categories (1-year, 5-year, 10-year old secondary forests and a mature secondary forest of about 80 years old) were studied. Vegetation parameters were measured by quadrat method. Forty quadrats $(30 \mathrm{~m} \times 30 \mathrm{~m})$, ten in each secondary forest categories were delineated for soil sampling and for the measurement of vegetation structural properties. Twenty composite soil samples were collected in each secondary forest category and analyzed for organic matter, $\mathrm{pH}$, available phosphorus, total porosity, ECEC (effective cation exchange capacity) and water holding capacity. Vegetation structural properties for each of the quadrats were measured using appropriate field measurement techniques. Multiple linear regression was used to investigate the relationship between the vegetation structural properties and soil properties. The result of multiple linear regression showed that soil organic matter, total porosity, water holding capacity, available phosphorus and ECEC were the most outstanding soil factors influencing the regenerative capacity of the vegetation structural properties in secondary forests.
\end{abstract}


Relationship between Soil and vegetation Structural Properties of Secondary Forest regenerating...

Key words: Tree height, Tree density, Basal area, multiple regression, ECEC, Water holding capacity.

\section{Introduction}

Vegetation and soil display a circularly causal relationship, in that the latter provides support (anchorage, nutrient, moisture and habitat) for vegetation to grow successfully on the one hand, while vegetation provides protective envelop for soil against soil erosion and helps to maintain soil nutrient through nutrient recycling via litterfall and mineralization of litter. Therefore, vegetation and soil are interconnected and exert symbiotic effects on each other. Vegetation performs important functions in an ecosystem at different spatial scales. Vegetation strongly affects soil characteristics, including soil volume, chemistry, and texture, which in response affect various vegetation characteristics, including productivity, structure, and floristic composition (Brant et al. 2006).

Soil nonetheless is essential to ecosystem and agricultural sustainability and production because it supplies many of the essential requirements such as water, nutrients, anchorage, oxygen for roots, and moderate temperature for plant growth (Jamieson et al. 2002, van der Maarel 2004). Soil performs a very important role in nature, providing nutrients for plant to grow as well as habitat for millions of microand macro-organisms (Eni et al. 2011). Healthy soil enables vegetation to thrive, releases oxygen, holds water and diminishes destructive storm runoff, breaks down waste materials, binds and breaks down pollutants, and serves as the first course in the larger food chain (Marx et al. 1999, Rodriguez-Iturbe 2000). The degradation of the soils and vegetation impact negatively on the soil and vegetation and affect their ability to perform these functions. The reciprocal relationship between soil and vegetation demands a multivariate approach in order to determine important vegetation and soil properties that sustain this reciprocal relationship. Based on this, multivariate analytical techniques (such as multiple linear regression, principal component analysis, canonical correlation analysis, detrended canonical correlation analysis, factor analysis, canonical correspondence analysis and stepwise multiple regression among others) are very useful in the analysis of soil and vegetation as each consists of data corresponding to a large number of variables.

The lowland tropical secondary forest of Orogun in Delta state Nigeria is a secondary forest regenerating from degraded abandoned rubber plantation and food crops agriculture. Plantation agriculture of rubber, which in most instances proved to be little more permanent than bush fallowing, is a major cause of secondary forest in Delta state area of Southern Nigeria. Most of the rubber plantations in Orogun are abandoned today because of soil nutrient impoverishment, animal pests, plant diseases and death of rubber trees arising from inappropriate tapping. Therefore, most of the areas that were occupied by rubber plantations are now occupied by secondary 
forests in different stages of regeneration. There is therefore the need to identify the basic soil and vegetation parameters encouraging the regenerative capacity of this once degraded secondary forest and impoverished soil.

In most parts of the world, studies explaining the relationships between soil and vegetation have been conducted in the past by scholars in the fields of ecology, geography, forestry, and soil science using varying multivariate approaches. For instance, studies on soil-vegetation relationships of saline localities have been carried out in different parts of the world (Li 1993, Bui and Henderson 2003, El-Ghani and Amer 2003, Li et al. 2008); studies on soil-vegetation relationships in tropical rainforests have also been conducted in different parts of the tropical world (Feng et al. 2007, Du et al. 2007). In Nigeria, studies on soil-vegetation interrelationships in the rainforest zones focused on: (1) secondary forests following shifting cultivation system of agriculture (Aweto 1981a), (2) coastal mangrove swamps (Ukpon 1994) and (3) the Tinapa Resort of Cross River state-which is a secondary forest following series of anthropogenic disturbances outstandingly food crop cultivation, fuelwood exploitation, and illegal logging activities (Eni et al. 2011). There appears to be no study on the relationships between soil and vegetation structure of secondary forests regenerating from degraded abandoned rubber plantation in Nigeria and other parts of the world. This study sets out to fill this gap. The aim is to identify significant vegetation structural properties that help to restore the fertility of the soil for agricultural productivity and to identify the soil properties that help to sustain the regeneration of vegetation structural properties.

\section{Materials and methods}

The study area (Orogun) which is part of the low deltaic plain of southern (Niger Delta) Nigeria is bordered to the north by Abraka in Ethiope East Local Government, to the south by Emevor Isoko North Local Government and to the west by Kokori in Ethiope East local Government and to the east by Abbi and Amai in Ukwuani Local Government Areas respectively (Fig. 1). The study area is located between latitudes $5^{0} 26^{\prime} \mathrm{N}$ and $5^{\circ} 48^{\prime} \mathrm{N}$ and between longitudes $5^{\circ} 51^{\prime} \mathrm{E}$ and $6^{\circ} 12^{\prime} \mathrm{E}$. Other details of the study area are contained in Ichikogu (2011a, b, c). 


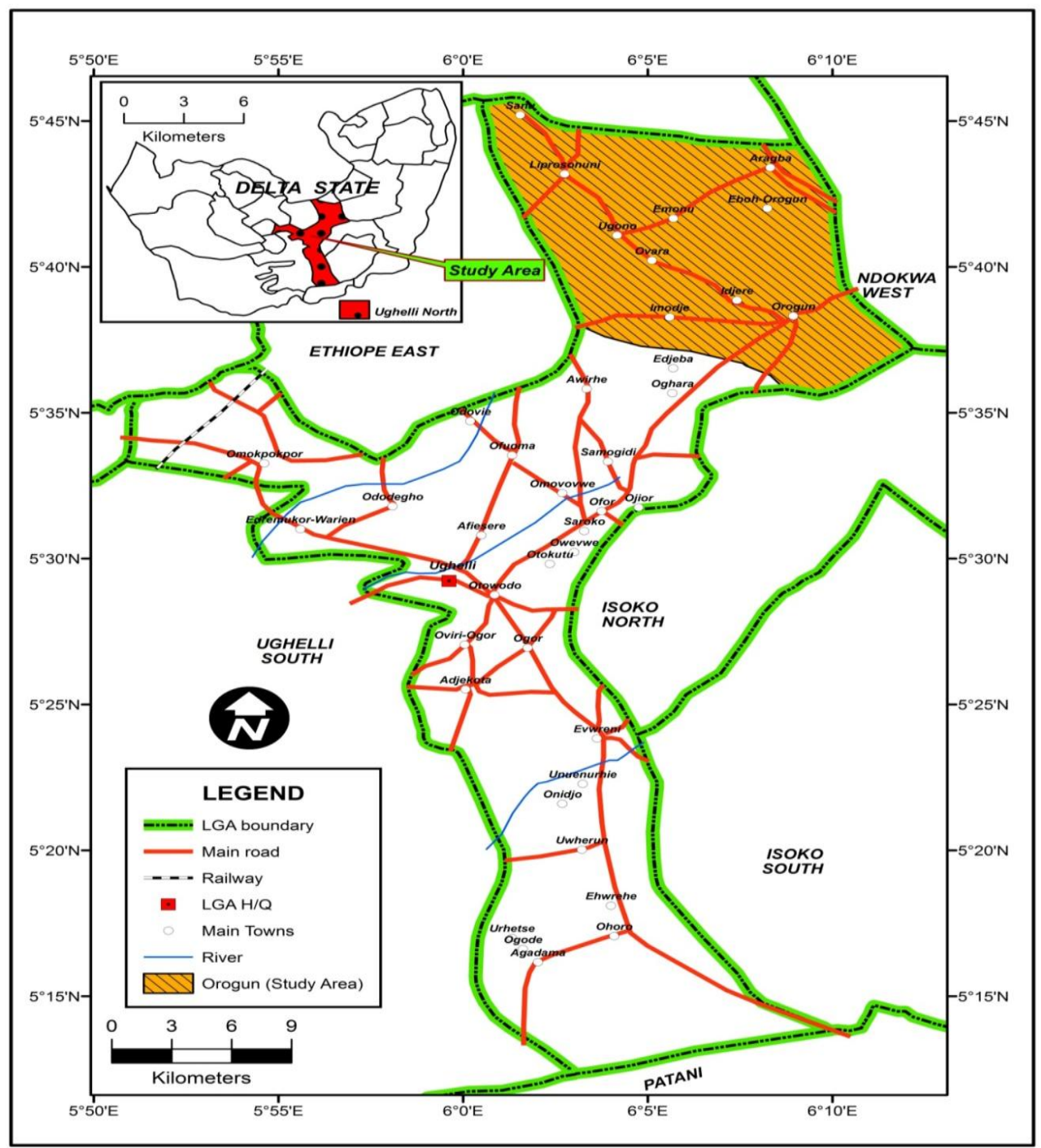

Fig. 1: Map of Ughelli North showing the study area

Ichikogu (2011c) reported that there are significant improvements in soil physicochemical properties and vegetation structural parameters with increasing age of secondary forest. Based on this, fallow plots of 1, 5 and 10 year old, and a mature forest plots reflecting different degrees of soil fertility and vegetation structural regeneration were selected for study. All the secondary forests categories and the 
mature forest had the same parent material and were on comparable flat crestal interfluve sites to ensure that catenary variations in soil properties were minimized.

Within each of the secondary forest age categories, ten sample plots of 30 metres X 30 metres were delimited for investigation. Soil sampling follows the procedure described by Boone et al (1999). Soil samples were collected from five points which were located randomly within the 30 metres X 30 metres plots at predetermined depths of $0-10 \mathrm{~cm}$ and $10-30 \mathrm{~cm}$ (which shall be referred to as top-soil and sub-soil in subsequent sections) using a core sampler. The approach of sampling from predetermined depths was adopted in order to ensure comparability among samples collected from different sample quadrats in geographically separate locations since the thickness of the soil profile vary from place to place (Ichikogu 2011a). The limit of the top $30 \mathrm{~cm}$ of the soil was chosen for two reasons. Firstly, the limit of the visible humic horizons usually lies here and secondly, numerous observations of root distributions and direct measurement of labeled-phosphorus uptake (Nye and Foster 1960) indicates that in humid regions nearly all the feeding of the annual crops which replace the fallows takes place within this zone. A total of 100 soil samples were collected from each age category on the basis of 50 samples from topsoil and 50 samples from subsoil. These samples of soil were mixed into a composite of 10 composites for each soil depth (on the basis of five samples constituting a composite sample) for chemical analysis. Since there were three age categories and a mature forest, a total of 80 soil composite samples were used for chemical and physical analysis. Eighty composite samples collected were air-dried, crushed thoroughly mixed and passed through a $2 \mathrm{~mm}$ mesh sieve in readiness for analysis.

\section{Mature forest in Orogun}

\section{0-year old fallow in Orogun}

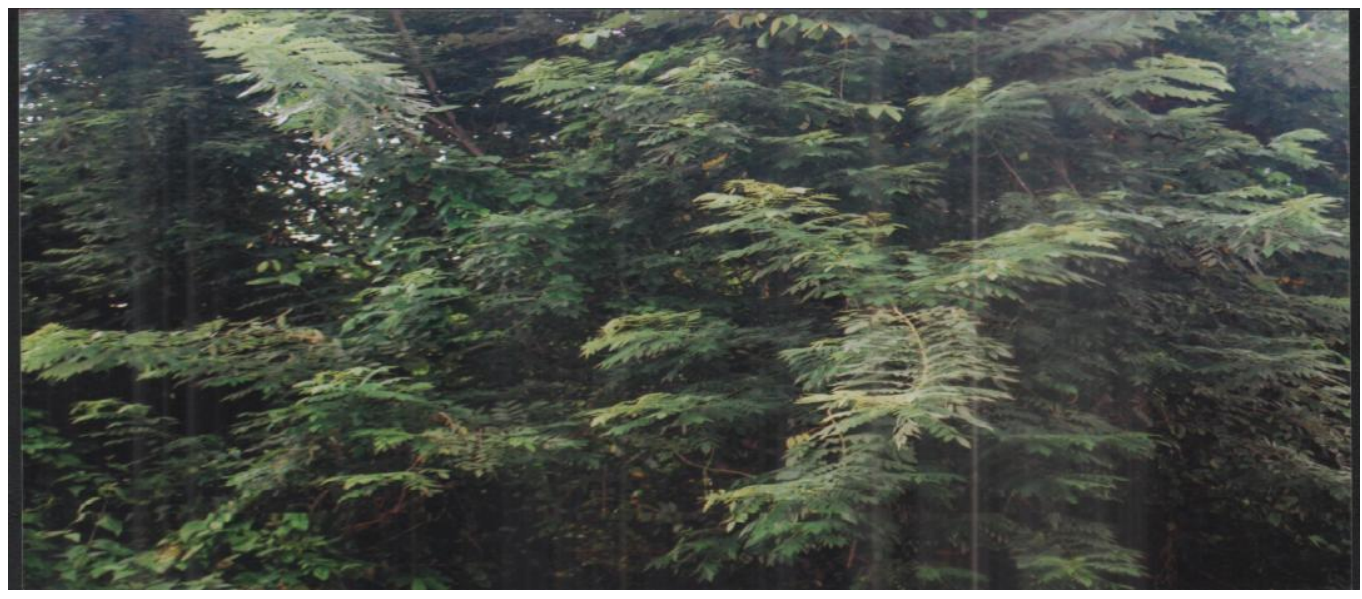


Relationship between Soil and vegetation Structural Properties of Secondary Forest regenerating...

5-year old fallow in Orogun
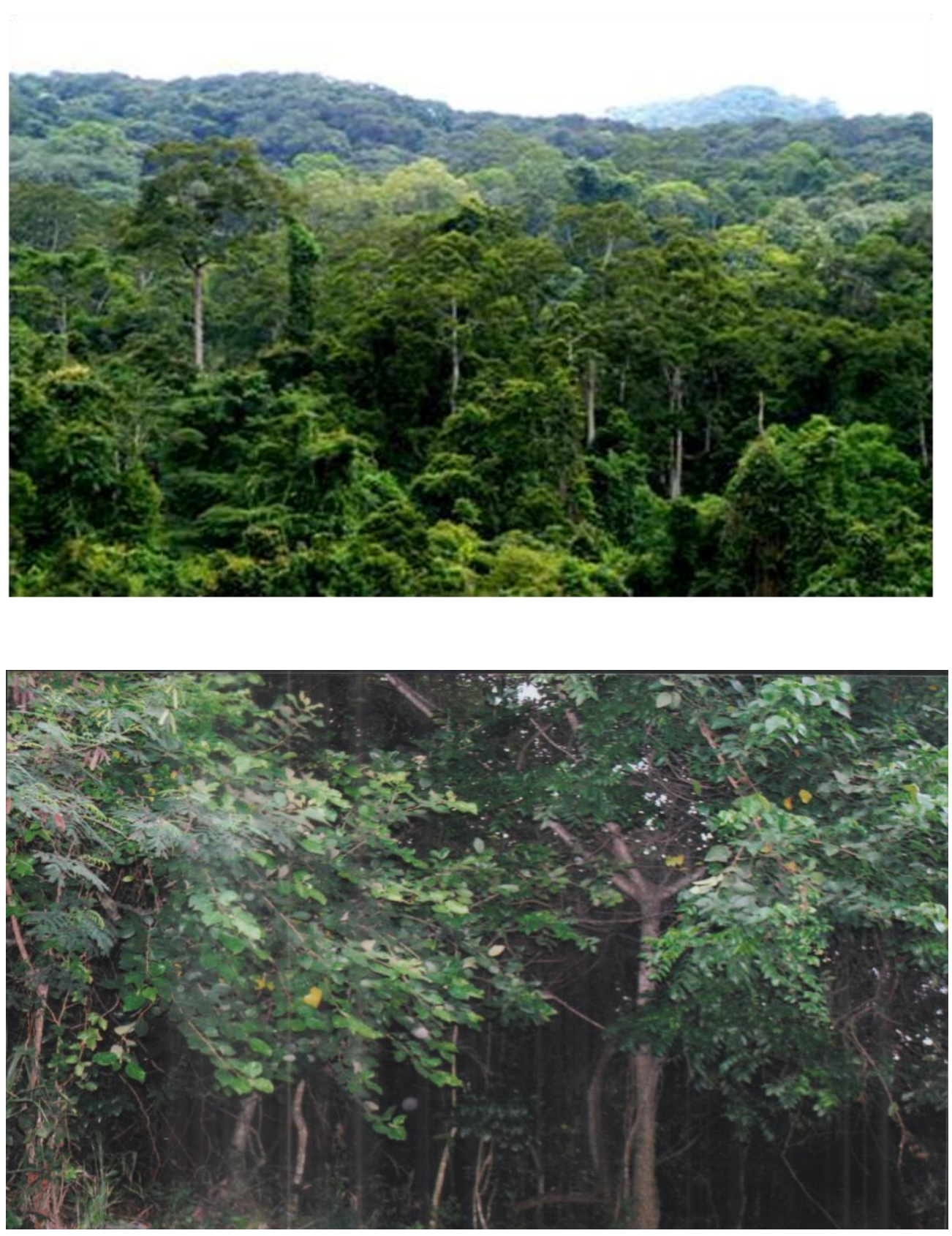

Copyright $\odot$ IAARR 2014: www.afrrevjo.net Indexed AJOL: www.ajol.info 
1-year old fallow in Orogun

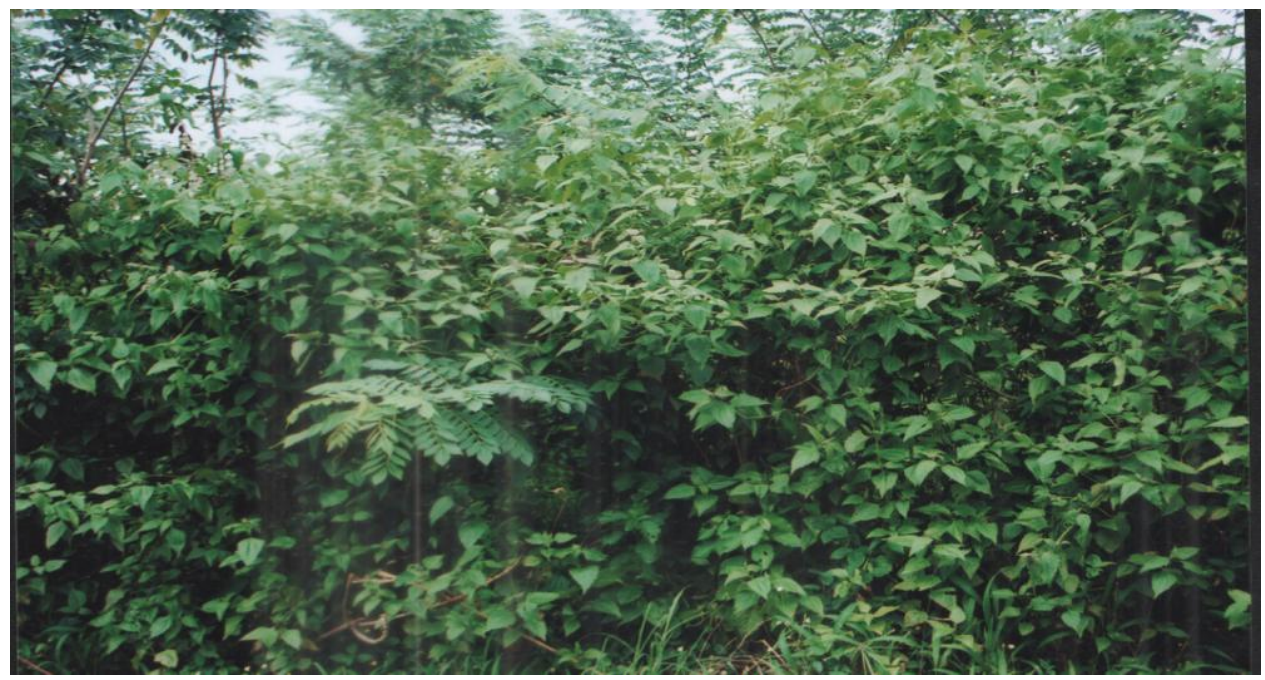

\section{Plate 1: Fallows and secondary forests in different stages of regeneration}

The soil properties analyzed are soil organic matter, bulk density, and total porosity, water holding capacity, soil $\mathrm{pH}$, available phosphorus and effective cation exchange capacity. Soil pH was determined potentiometerically (Aweto, 1981a). To determine the soils water holding capacity, 5 soil samples were collected at $0-10 \mathrm{~cm}$ and $10-30$ $\mathrm{cm}$ soil depths respectively in each of the 30 X 30 metres plots, air dried and taken to the laboratory for analysis. The soil water holding capacity was determined as the difference between field capacity (FC) and permanent wilting point (PWC). Bulk density was analyzed by the core method. Total porosity values were calculated from bulk density values using an assumed particle density value of $2.65 \mathrm{~g} / \mathrm{cm}^{3}$ (Vomocil 1965). Available phosphorus was determined by leaching the soil with Bray and Kurtz solution $\left(0.025 \mathrm{M} \mathrm{HCL}\right.$ to $\left.0.03 \mathrm{MN} \mathrm{H}_{4} \mathrm{~F}\right)$. The concentration of available phosphorus was determined calorimetrically with "spectronic 20" spectrophotometer after the colour had been developed in soil extract using the ascorbic acid method (Molindo, 2008). Effective cation exchange capacity was determined by the summation method (Chapman, 1965); summation of the exchangeable cations in Ichikogu (2011a). The Walkley-Black method was used in this study to determine the soil organic carbon content, while the soil organic carbon was converted to soil organic matter by multiplying the organic carbon values by a factor of 1.729 (Walkley and Black 1934). 
Vegetation biomass parameters such as tree height, tree diameter and tree density and basal area were measured in five sub-plots selected in each 30 metres X 30 metres plot. For the purpose of the field investigation, a tree was defined operationally as woody plant of erect habit with a minimum breast height diameter (i.e. at the height of $1.5 \mathrm{~m}$ above the ground) of $2 \mathrm{~cm}$. For the measurement of tree diameter, the circumferences of the tree trunks were measured at breast height with flexible measuring tape around the trunk of the trees. The circumference measurements were then converted into diameter values by dividing circumference values by 3.142 (that is, $\Pi$ ). The diameters of saplings in the 1-year old secondary forest plots were determined at the ground level as was done by Aweto (1981a). Tree basal area was measured by using the equation based on the formula for the area of a circle (Area $=$ $\left.\Pi r^{2}\right)$.

Where:

$\mathrm{r}=$ radius

$\Pi=3.142$

And the formula for radius $(\mathrm{r})=\underline{\text { diameter }}=\underline{\mathrm{DBH}}$

22

Therefore:

Tree basal area $=\underline{(\mathrm{DBH}}^{2} \Pi$

Where

$\mathrm{DBH}=$ Diameter at breast height in centimetres.

After calculating the individual tree basal area using the above formula the total tree basal area per hectare was obtained by multiplying the average individual tree basal area by the total number of trees per hectare.

The height of trees was measured by measuring the angle of the tree tops and the distance from the point of observation with Abney level and measuring tape respectively (i.e. the angel of the tree was measured using the Abney level while the tape was used to measure the distance from the point of observation to the tree). Based on these measurements, tree height was calculated using the formula:

$\mathrm{H}=\mathrm{X} \tan \Theta$

Where

$\mathrm{H}=$ Height of tree 
$\mathrm{X}=$ Distance of observer from tree

$\Theta=$ Angle of tree top from observer

The tree density was obtained by counting the number of individual that have attained tree status in each 30 metres X 30 metres plot and subsequently converting the values to tree density per hectare.

\section{Data analyses}

Multiple regression was used to model the relationship between soil organic matter, $\mathrm{pH}$, ECEC, water holding capacity, total porosity and available phosphorus on vegetation structural properties (tree height, tree density, tree diameter, tree basal area and estimated aboveground biomass) using the panel/pooled regression tools in the Eviews software package. To do this the ten soil composite samples analyzed in the laboratory for the 1-year old fallow form sample number 1 to 10 , those of the 5-year old fallow, 10-year secondary forest and mature forest form sample 11-20, 21-30 and 31-40 respectively, which were used in the regression, while the values of each of the soil structural properties for each of the ten quadrats in the 1-year old fallow, 5-year old fallow, 10-year old secondary forest and the mature forest form sample number 1$10,11-20,21-30$ and 31-40 used in the regression analysis (i.e. soil physicochemical properties under each quadrat was recorded against the corresponding vegetation structural property values for that quadrat for the regression analysis). The independent variables (soil parameters) were tested for multicollinearity using the criteria of Hauser (1974).

\section{Results}

Table 1 shows the mean values of the vegetation structural properties in each of the secondary forest categories and the mature forest. Table 2 shows the mean values of the soil physic-chemical properties used for the stepwise regression analysis.

\section{Relationships between soil properties and vegetation structural properties - multiple linear regression}

The relationships between vegetation structural properties and soil properties are shown in the regression models below:

\section{Basal Area of Vegetation}

Regression of basal area on the seven soil variables produced a regression model of the form:

$$
\mathrm{LOGBA}=-18.96+5.64 \mathrm{ECEC}+1.01 \mathrm{TP}+0.22 \mathrm{SOM}+0.39 \mathrm{WHC}
$$

Where: 
LOGBA $=$ Logarithm of Basal area

$\mathrm{ECEC}=$ Effective cation exchange capacity

$\mathrm{TP}=$ Total porosity

$\mathrm{SOM}=$ Soil organic matter

WHC $=$ Water holding capacity

Analysis of variance test for the significance of the regression coefficients yielded an ' $F$ ' ratio of 138.116 which is significant at 0.01 levels of significance. The six soil parameters jointly explain $95.33 \%$ of the variation in vegetation basal area. However, ' $t$ ' test for the significance of each of the soil variables towards the explanation of the variation in basal area shows that five out of the six soil parameters entered into the regression are significantly correlated with basal area. These five soil parameters are: soil organic matter, total soil porosity, soil water holding capacity, effective cation exchange capacity and soil available phosphorus.

Soil $\mathrm{pH}$ is correlated with basal area but the ' $\mathrm{t}$ ' value is not significant at 0.05 level of significance of the ' $\mathrm{t}$ ' statistics. The soil $\mathrm{pH}$ is therefore not significantly correlated with vegetation basal area.

\section{Tree Density}

Regression of tree density on the six soil parameters produced a regression model of the form.

$\mathrm{TD}=-3.48+2.14 \mathrm{SOM}+10.25 \mathrm{ECEC}+0.63 \mathrm{TP}+0.84 \mathrm{WHC}$

Where

$\mathrm{TD}=$ Tree density

All the other variables are as defined earlier

From the regression in table 4 , all the variables considered except soil $\mathrm{pH}$ bear positive relationships with tree density. However, the influence of $\mathrm{pH}$ and available phosphorus in explaining variation in tree density are not statistically significant. The positive and significance contributions of soil organic matter, effective cation exchange capacity, total porosity and water holding capacity in explaining variation in tree density is consistent with the findings of many previous studies (e.g. Aweto 1981, Sanchez 1991, Raphael et al, 2000).

\section{Tree Height}

Regression of tree height on the six soil parameters produced a regression model of the form: 
$\mathrm{TH}=2.44+0.843 \mathrm{SOM}+0.146 \mathrm{WHC}+6.70 \mathrm{ECEC}+1.60 \mathrm{TP}$

Where

$\mathrm{TH}=$ Tree height

All the other variables are as defined earlier

All the six soil variables jointly explain $62 \%$ of the variation in tree height. All the soil variables except $\mathrm{pH}$ have positive relationships with tree height. Three soil variables - soil organic matter, effective cation exchange capacity and water holding capacity are statistically significant in explaining variation in tree height, while the remaining three- total porosity, $\mathrm{pH}$ and available phosphorus are not statistically significant in explaining variation in tree height.

\section{Tree Diameter}

The regression of tree diameter on the six soil explanatory variables yielded an ' $F$ ' value of 103.24 which is significant at 0.0001 levels of the ' $F$ ' statistics. The six soil explanatory variables jointly explain $66.38 \%$ of the variation in tree diameter. The regression of tree diameter on the six soil parameters produced a regression equation of the form:

$\operatorname{LogTDA}=26.85+2.01 \mathrm{SOM}+1.57 \mathrm{ECEC}+5.78 \mathrm{WHC}+0.07 \mathrm{TP}+0.004 \mathrm{P}$

Where

$\log \mathrm{TDA}=$ Logarithm of tree diameters

All the other variables are as earlier defined.

The six soil variables except soil $\mathrm{pH}$ have positive relationships with tree diameter. However, the influences of $\mathrm{pH}$ and available phosphorus in explaining variation in tree diameter are not statistically significant. The influences of soil organic mater, total porosity, water holding capacity and effective cation exchange capacity are positive and statistically significant at $\mathrm{P}<0.05$. This findings is consistent with those of Aweto (1981a) (who reported positive and significant relationships between these soil variables and tree size) and that of Bakhtiar and Ali (2011).

Moving away from the individual regression models, we now turn to the goodness of the models in general. From the results presented in tables 3-6, and going by the diagnostic statistics of the models namely R-squared, and ' $F$ ' statistics, it can be inferred that the models constructed adequately explain the relationships between soil physio-chemical properties and vegetation structural parameters.

The data collected were pooled and analyzed using the panel/pooled regression tools in the E-views software package. The results obtained show that soil organic matter, water holding capacity, total porosity and effective cation exchange capacity are 
significantly related to the vegetation structural parameters (tree height, tree density, tree basal area and tree diameter). While the soil $\mathrm{pH}$ and available phosphorus are not statistically significantly related to the vegetation parameters.

\section{Discussion}

The result of multiple regression analysis shows that vegetation structural parameters (tree height, tree diameter, tree density and basal area) are significantly related to soil physico-chemical properties. The signs of the regression analysis suggest that the vegetation structural parameters are negatively related to soil $\mathrm{pH}$ and soil bulk density. This is not strange because increase aboveground biomass, tree density, tree basal area, tree diameter and tree height result in increase litter fall and increase root concentration in the soil resulting in increase microbial activities and rapid withdrawal of soil nutrients (exchangeable cations) by plants thereby leading to decrease in soil $\mathrm{pH}$.

It is often assumed that forest biomass is related to soil nutrient status (Aweto 1981); this study corroborates that assumption as revealed by the significant correlation between aboveground biomass and the soil physico-chemical properties. However, this assertion should be taken with caution. It is noteworthy that, despite its huge biomass, the 10-year fallow has soils that have lower concentration of nutrients whilst the soils under the small aboveground biomass 5-year old secondary forest have comparatively high concentrations of soil nutrients probably due to rapid nutrient immobilization by the growing vegetation that is associated with transition from pseudo-woody fallow by the fifth year to woody secondary forest by the tenth year. In contrast the mature forests have comparatively higher aboveground biomass and soil nutrients than both the 10-year and 5-year old secondary forests. Many factors, including different patterns of regeneration, might influence forest structural properties. A proportional relationship between soil nutrient concentrations and forest structural properties would be more likely in young secondary forests (as long as other factors are not limiting) than in mature secondary forests with efficient nutrient cycling and long term nutrient accumulation in living matter from the soil. This also was the opinion of Toky and Ramakrishnan (1983) who reported rapid depletion of soil nutrients by the $10^{\text {th }}$ year of fallow.

\section{Conclusion}

In general, this study highlighted the interactions between soil physico-chemical properties and vegetation structural properties of secondary forests regenerating from degraded abandoned rubber plantation in south-southern Nigeria. It revealed that soil organic matter, total porosity, water holding capacity, available phosphorus and effective cation exchange capacity significantly affect vegetation structural properties. Based on these results, in the management of secondary forest regenerating from degraded plantation specific consideration should be given to 
changes in soil physico-chemical properties. It is suggested that if the structural properties of the vegetation is to be improved, the fertility of the soil is to be sustained or enhanced, and the degeneration of the secondary forests regenerating from degraded abandoned rubber plantation is to be circumvented secondary forest regenerating from degraded abandoned plantation should be left for at least five to ten years to grow fallow before they are recultivated.

Table 1: Soil physic-chemical characteristics (Topsoil), $N=10$

\begin{tabular}{l|llll}
$\begin{array}{l}\text { Soil } \\
\text { properties }\end{array}$ & 1-year old & 5-year old & 10-year old & MF \\
\hline OM & 2.12 & 3.09 & 4.74 & 5.10 \\
WHC & 40.29 & 48.16 & 61.17 & 64.04 \\
\hline TP & 56.11 & 56.98 & 59.13 & 61.89 \\
pH & 6.14 & 5.81 & 5.3 & 6.0 \\
\hline P & 4.91 & 8.81 & 4.57 & 11.6 \\
ECEC & 7.14 & 9.07 & 8.04 & 10.18
\end{tabular}

Note: $\mathrm{OM}=$ Organic matter $(\%), \mathrm{WHC}=$ Water holding capacity $(\%), \mathrm{TP}=$ Total porosity $(\%), \mathrm{P}=$ Available phosphorus $(\mathrm{Mg} / \mathrm{g}), \mathrm{MF}=$ Mature forest.

Table 2: Mean tree density (number of trees DBH $>2 \mathrm{~cm} / \mathrm{ha}$ ), tree height (in metres), tree diameter (in $\mathrm{cm}$ ), Tree basal area (in $\mathrm{m}^{2} \mathrm{ha}^{-1}$ )

\begin{tabular}{lllll} 
& \multicolumn{2}{c}{ Fallow age Categories } & \\
Vegetation & 1-year fallow & 5 -year fallow & 10-year fallow & MF \\
parameters & & & & \\
Tree density & 56 & 1488 & 2840 & 2168 \\
Tree height & 1.74 & 4.18 & 6.44 & 8.77 \\
Tree diameter & 1.03 & 4.75 & 9.23 & 20.65 \\
Tree basal area & 0.16 & 2.76 & 18.21 & 72.99
\end{tabular}


Relationship between Soil and vegetation Structural Properties of Secondary Forest regenerating...

Table 3: Ordinary least square multiple regression of basal area on the six soil explanatory

\begin{tabular}{l|llllll}
$\begin{array}{l}\text { Independent } \\
\text { variables }\end{array}$ & B coefficient & Std error & T value & $\begin{array}{l}\text { Significant } \\
\text { level of } \mathbf{~}\end{array}$ & $\mathbf{R}^{\mathbf{2}}$ & F value \\
\hline ECEC & 5.6432 & 0.9816 & 5.74898 & 0.0000 & 0.9533 & 138.116 \\
TP & 1.010241 & 0.4814 & 2.0985 & 0.0316 & & \\
\hline SOM & 0.2243 & 0.1042 & 2.1526 & 0.0102 & & \\
WHC & 0.3946 & 0.1858 & 2.1238 & 0.0146 & & \\
\hline P & -1.4897 & 0.8044 & -4.1050 & 0.0001 & \\
pH & -1.3060 & 0.7564 & -1.7266 & 0.0939 & \\
Constant & -18.9600 & 6.9426 & -2.7310 & 0.0092 & &
\end{tabular}

Table 4: Ordinary least square multiple regression of tree density on the six soil explanatory variables

\begin{tabular}{|c|c|c|c|c|c|c|}
\hline $\begin{array}{l}\text { Independent } \\
\text { variables }\end{array}$ & $\begin{array}{l}\text { B } \\
\text { coefficient }\end{array}$ & $\begin{array}{l}\text { Std } \\
\text { error }\end{array}$ & $\begin{array}{l}\text { 't'' } \\
\text { value }\end{array}$ & $\begin{array}{l}\text { 't' significant } \\
\text { level }\end{array}$ & $\mathbf{R}^{2}$ & $\begin{array}{l}\text { F } \\
\text { value }\end{array}$ \\
\hline SOM & 2.1422 & 0.7001 & 3.0598 & 0.0023 & 0.8946 & 41.133 \\
\hline ECEC & 10.2536 & 3.0422 & 3.3705 & 0.0006 & & \\
\hline $\mathrm{TP}$ & 0.6324 & 0.3292 & 1.9210 & 0.0321 & & \\
\hline WHC & 0.8421 & 0.3342 & 2.5197 & 0.0134 & & \\
\hline $\mathrm{pH}$ & -2.2436 & 1.3963 & -1.6068 & 0.0864 & & \\
\hline $\mathrm{P}$ & 0.3624 & 0.8616 & 0.4206 & 0.6026 & & \\
\hline Constant & -3.4813 & 12.6965 & -0.2742 & 0.8022 & & \\
\hline
\end{tabular}

Table 5: Ordinary least square multiple regression of tree height on the six soil explanatory variables

\begin{tabular}{l|llllll}
$\begin{array}{l}\text { Independent } \\
\text { variables }\end{array}$ & $\begin{array}{l}\mathbf{B} \\
\text { coefficien } \\
\mathbf{t}\end{array}$ & Std error & 't' values & $\begin{array}{l}\text { 't' } \mathbf{c} \text { significant } \\
\text { levels }\end{array}$ & $\mathbf{R}^{2}$ & $\mathbf{F}$ \\
\hline SOM & 0.7913 & 0.2010 & 3.9368 & 0.0001 & 0.6203 & 17.341 \\
ECEC & 7.0203 & 2.1042 & 3.3363 & 0.0005 & & \\
\hline WHC & 0.1711 & 0.0132 & 12.9621 & 0.0000 & \\
TP & 1.5633 & 2.0011 & 0.7812 & 0.3827 & \\
\hline pH & -1.5004 & 1.2161 & -1.2338 & 0.2457 & \\
P & 0.6382 & 0.8233 & 0.7752 & 0.3934 & & \\
Constant & 2.7354 & 11.1891 & 0.2445 & 0.8341 & &
\end{tabular}


Table 6: Ordinary least square multiple regression of tree diameter on the six soil explanatory variables

\begin{tabular}{l|llllll}
$\begin{array}{l}\text { Independent } \\
\text { variables }\end{array}$ & $\begin{array}{l}\text { B } \\
\text { coefficient }\end{array}$ & $\begin{array}{l}\text { Std } \\
\text { error }\end{array}$ & 't' values & $\begin{array}{l}\text { 't' significant } \\
\text { levels }\end{array}$ & $\mathbf{R}^{2}$ & $\mathbf{F}$ \\
\hline SOM & 1.0240 & 0.6001 & 1.7063 & 0.0932 & 0.6638 & 103.2436 \\
ECEC & 0.7524 & 0.0426 & 17.6618 & 0.0000 & \\
\hline WHC & 4.8716 & 1.9924 & 2.4451 & 0.0241 \\
TP & 0.0621 & 0.0086 & 7.2209 & 0.0000 & \\
\hline pH & -0.0064 & 0.3923 & -0.0163 & 0.9836 & \\
P & 0.0042 & 0.0018 & 2.3333 & 0.0283 & \\
Constant & 14.8502 & 8.3647 & 1.7753 & 0.0821
\end{tabular}

\section{References}

Aweto, A. O. (1981c) Secondary succession and soil fertility restoration in southwestern Nigeria: soil and vegetation interrelationships, Journal of Ecology, vol. 69, pp. 957-963.

Bakhtiar, F. \& Ali R. I. (2011). Effects of some environmental factors on plant species diversity in the mountainous grasslands in Iran. International Journal of Natural Resources and Marine Sciences, 1 (1) 45-52.

Boone, D.R.; Grigal, D.F.; Solis, P.; Ahrens, R.J. \& Armstrong, D.E. (1999). Soil sampling, preparation, archiving and quality control. P. 3-27. In Robertson et al (ed,) Standard soil methods for long term ecological research. Oxford University Press, New York.

Bui, E. N. \& Henderson, B. L. (2003) Vegetation indicators of salinity in northern Queensland. Austral Ecology, 28 (5) 539-552.

Chapman, H.D. (1965). Cation exchange capacity. In: Black C.A. (ed). Methods of soil analysis-chemical and microbiological properties. Agronomy, 9: 891901.

Du, F. Shao, H. B., Shan, L., Liang, . Z. S. \& Shao, M. A. (2007). Secondary succession and its effects on soil moisture and nutrition in abandoned oldfields of hilly region of Loess Plateau, China, Biointerfaces, Vol. 58, no. 2, pp. 278-285. 
Relationship between Soil and vegetation Structural Properties of Secondary Forest regenerating...

El-Ghani, M. M. \& Amer, W. M. (2003) Soil-vegetation relationships in a coastal desert plain of southern Sinai, Egypt. Journal of Arid Environments, 55: (4) 607-628.

Eni, D. D., Iwara, A. I. \& Offiong, R. A. (2011). Analysis of Soil-Vegetation Interrelationships in a South-Southern Secondary Forest of Nigeria. International Journal of Forestry Research. doi:10.1155/2012/469326

Feng, D. Zongsuo, L. Xuexuan, Z., Lun, . S. \& Xingchang, Z. (2007) Community biomass of abandoned farmland and its effects on soil nutrition in the Loess Hilly region of Northern Shaanxi, China. Acta Ecologica Sinica, 27, (5) 1673-1683.

Hauser, D.P. (1974). Some problems in the use of stepwise regression techniques in geographical research. Canadian Geographer, 18, 148-158.

Ichikogu, V.I (2011a). The dynamics of soil physical properties and exchangeable cations in secondary forests regenerating from degraded abandoned rubber plantation (Hevea brasiliensis) in Orogun area of Southern Nigeria. Ethiopian Journal of Environmental Studies and Management, 4 (2) 117126

Ichikogu, V.I (2011b). Organic matter dynamics in soils regenerating from degraded abandoned rubber plantation Orogun area of the rainforest zone of southern Nigeria. Ethiopian Journal of Environmental Studies and Management, 4 (4) $1-7$

Ichikogu, V.I (2011c). Soil fertility rejuvrnation following the abandonment of degraded rubber (Hevea brasiliensis) plantation in Orogun Area of Southern Nigeria. International Journal of Architecture and Built Environment, 3 (1) 99-104

Ichikogu, V.I (2012a). Total nitrogen and available phosphorus dynamics in soils regenerating from degraded abandoned rubber plantation in Orogun area of the rainforest zone of southern Nigeria. Ethiopian Journal of Environmental Studies and Management, 5 (1) 92-99

Jamieson, T., Gordon, R., Cochrane, L., and Patterson, G. (2002) "Fundamental aspects of soil-water-plant relationships," Tech. Rep., Resource Stewardship Division, NS Department of Agriculture and Fisheries-Truro, Nova Scotia.

Li, X. D. (1993). Canonical analysis and the principal components analysis of plant community with its environmental factors in the yellow river delta," Acta Botanica Sinica, vol. 35, pp. 139-143. 
Li, W., Xiao-Jing, L. M. Khan, A., and Gul, B. (2008) Relationship between soil characteristics and halophytic vegetation in coastal region of north China. Pakistan Journal of Botany, 40: (3), 1081-1090.

Marx, J., Bary, A., Jackson, S., McDonald, D., and Wescott, H. (1999). The Relationship Between Soil and Water-How Soil Amendments and Compost Can Aid in Salmon Recovery.

Molindo, W.A. (2008). Determination of the nutrient status of soil after incubation with organic residues for different days in Benin City, Nigeria. World journal of agricultural sciences, 4(6): 731-736.

Raphael, J.M. Patrice, C. Jean, T. and Jean-Luc, C. (2000). Relationships between abiotic and biotic soil properties during fallow periods in the Sudanian zone of Senegal. Applied Soil Ecology, 14: 89-101.

Rodriguez-Iturbe, I. (2000). "Ecohydrology: a hydrologic perspective of climate-soilvegetation dynamics," Water Resource Research, vol. 36, no. 1, pp. 3-9.

Silver, W.L.; Ostertag, R. and Lugo, A.E. (2000). The potential for carbon sequestration through reforestration of abandoned tropical agricultural pasture lands. Restoration ecology, 8: 394-407.

Szott, L. T. Fernandes, C.M. and Sanchez, P.A. (1991). Soil-plant interactions in agroforestry systems. Forest Ecology and Management, 45: 127-152.

Toky, O.P. and Ramakrishnan, P.S. (1983). Secondary succession following slash and burn agriculture in north-eastern India II: Nutrient cycling. Journal of ecology, 71: 746-753.

Ukpong, I. E. (1994). Soil-vegetation interrelationships of mangrove swamps as revealed by multivariate analyses. Geoderma, 64: (1-2), 167-181

van der Maarel E. (2004). Vegetation Ecology, Blackwell, Oxford, UK,

Vomocil, J. A. (1965). Porosity. In Black, C . A. (Ed.). Methods of soil analysis. American Society of Agronomy, Madison, 299-314

Walkley, A. and Black, I.A. (1934). An examination of the Detjareff method for determining soil organic matter and a proposed modification to the chromic acid titration method. Soil science 37: 29-38. 